\title{
BIOCHEMICAL CHARACTERIZATION OF SOME CYANOBACTERIA
}

\author{
Rajkumar Khapekar $^{1}$ and Lalita Sawarkar ${ }^{2}$ \\ 1. D.R.B. Sindhu Mahavidyalaya, Panchpaoli, Nagpur, Maharashtra. \\ 2. K.Z.S. College, Brahmni, Kalmeshwar, Maharashtra \\ Email ID : dr.khapekar@gmail.com, 1sawerkar5@gmail.com
}

Communicated: 13.02 .21

Revision : 13.03.21 \& 22.04.2021

Accepted: 06.05.2021

Published: 30.05 .2021

\begin{abstract}
:
Cyanobacteria are most commonly useful organism, storing reserve food in the form of cyanophycean starch, protein, carbohydrate, lipids and vitamins. These are the basic dietary supplements of human food. With the increasing population it is not possible for many countries to meet their food needs with the use of only conventional food sources. Hence it is suggested that unconventional sources of food specially drawn from cyanobacteria can be used to meet the needs of global food meet. In presented study, the biochemical constituents were analyzed in the term of total carbohydrates, total protein, total lipid contents and amino acid. Cyanobacteria used in this investigation were collected from various area of Nagpur and Wardha district. In this study it is showed that maximum amount of total carbohydrate (21\% dry weight) was recorded in Oscillatoria spp. Maximum amount of total protein (60\% dry weight) were recorded in Spirullina platensis and maximum amount of lipid (10.11\% dry weight) were recorded in Nostoc elipsosporum. Whereas, various common amino acids were also recorded in investigated cyanobacteria.
\end{abstract}

Keywords: Cyanobacteria, unconventional food, protein, carbohydrate, lipid.

\section{INTRODUCTION:}

The Cyanobacterial group is a diverse group of prokaryotic organisms that evolved in the Precambrian era, approximately 3.5 billion years ago - They are thought to be responsible for the oxygenation of the earth's atmosphere, 1 billion years after their appearance in the fossil record . The ability to survive in warm temperatures, high light, and low carbon dioxide concentrations has allowed the cyanobacteria to radiate into a broad range of habitats, including hot springs, frigid Antarctic lakes and soils, and extreme euryhaline and eurythermal environments. Cyanobacteria have a great deal of potential as source fine chemicals, as a biofertilizer and as a renewable fuel Recently, there has been increasing awareness about using cyanobacteria as bioremediation and pollution control agents, because they are environmental friendly and do not cause toxicity in other biotic components and their biomass production is in abundance and this can be used as a feed for animals, food industries, biotechnological applications and pharmaceutical industries (Rastogi and Sinha, 2009).

Cyanobacteria are one of the useful organisms widely used in food industries and in few biotechnological applications (Becker and Venkataraman,1967; Thajuddin and Subramanian, 2005).They store reserve food materials which can be used as the source of pigments, lipids, vitamins, proteins and certain secondary metabolites (Cardozo et al., 2007). Cyanobacterial protein has received worldwide attention for either as food supplement or as an alternative source of food. Some species of Anabaena, Nostoc and Spirulina are consumed as food due to their high protein and fiber content 
(Anupama, 2000). A large number of marine nitrogen fixing cyanobacteria serve as complete aquaculture feed source due to their nutritional quality and non toxic property.

At present, effort is being made on large-scale production of their metabolites for therapeutic use by culturing them under controlled laboratory conditions. In this work, the total carbohydrates, total proteins, total lipids and amino acids content of three species isolated from the study area located at Maharashtra state India were estimated to find their further uses.

\section{MATERIAL \& METHODS:}

The raw material employed in the experiments i.e. Spirulina platensis, Nostoc elipsosporum and Oscillatoria spp. collected from aquatic bodies of Wardhaand Nagpur regi on. Cells were cultivated in the culture media in the laboratory of P.G.T.D. Botany, RTM Nagpur University, Nagpur. Auxenic culture was made in the vessel, for desirable duration. Cell biomass was harvested by centrifugation and the pellet washed with $0.9 \%$ ammonium formate in order to partially desalt the sample and, after repeated centrifugation, the pellet was dried in shed (M.D. Mac`1as-S`anchez et al, 2007)

\section{BIOCHEMICAL ANALYSIS:}

Estimation of Chlorophyll a, Chlorophyll-b, total carotenoid - Pigment quantification was measured by spectrophotometrical method by (Dere ,et al., 1928).

Estimation of Protein - Estimation of protein in algae was carried out by Bradford method (S.Sadasivam and A.Manickam, 2008).

Estimation of Carbohydrate - Estimation of protein in algae was done by Anthrone method given by (S.Sadasivam and A.Manickam, 2008)
Estimation of Lipid - Estimation of oil in algae was done by Oil estimation method given by (S.Sadasivam, A.Manickam, 2008) and L.Govindarajan et.al.in JABU(4)

Determination of Amino acid - Amino acids in algae were estimated by following a method (Y.K.Chau, 1967).

\section{RESULT \& DISCUSSION:}

Not only Spirulina platensis but other two algae also showed carbohydrate, protein and lipid contents .Spirulina platensis shows highest protein content $60 \%(60 \%$ per gram of dry mass), Oscillatoria $s p$ shows $21 \%$ highest carbohydrate contain i.e.(21\%)and Nostoc elipsosporum shows $10.11 \%$ highest lipid contain(10.11\%) among selected algae.

Amino acid profile of cyanobacteria is given in the table shows that all 14 different amino acids were detected from Spirulina platensis and Nostoc elipsosporum. This profile shows that Oscillatoria $s p$. Contain all 13 amino acid except methionine. Somehow more or less similar findings also reported by Karanth Rama Rajeshwari and Madaiah Rajashekhar (2011). Further more study is needed for the use of carbohydrate, protein, lipid and amino acid as a source of food and energy for humans and animals.

\section{REFERENCES:}

Anupama, ravindra P (2000). Value added food: Single cell protein. Biotechnol. Adv. 18 : 459 -479 .

Becker E.W. and Venkataraman P.M. (1967). Production to utilization of the blue green alga Spirullina in India. Fd Agric 18. Pp. 497 -501 .

Dere S, Gunes T., Sivaci R. (1998). Spectrophotometric determination of Chl. A, Chl. B. and Total Caretenoid contents of some algal species using different solvents. Tr. Jr. of Botany; 22: $13-17$

Govindrajan L. Raut N. and Ahmed A. (2009). Novel solvent extraction for extracting of oil 
from algae biomass grown in desalina. Jr.of algal biomass utilization. $1: 18-28$

Karanth Rama Rajeshwari* and Madaiah Rajashekhar (2011).Biochemical Composition of Seven Species of Cyanobacteria Isolated from Different Aquatic Habitats of Western Ghats, Southern India. Int. Nat. Jr. of Brazilian archives of biology and technology. Vol 54 n 5. Pp 849-857

Karina H M Cardozo, Thais Guaratini, Marcelo P Barros, Vanessa R Falcao, Angela P Tonon, Norberto Lopes, Sara Campos, Moacir A Torres, Anderson O Souza Pio Colepicolo, Evnani Pinto (2007). Metabolites from algae with Economical Impact. Com Biochem Physiol Toxicol Pharmacol, 146 (1-2): 60 78.

M.D. Mac'ias-S`anchez , C. Mantell , M. Rodr'iguez, E. Mart'inez de la Ossa, L.M. Lubian , O. Montero (2007). Supercritical fluid extraction of carotenoids and chlorophyll a from Synechococcus sp. J. of Supercritical Fluids 39 (2007). Pp.323-329. Rastogi R and S inha R. (2009). Biotechnological and Industrial significance of cyanobacterial secondary metabolities. Biotechnology Advances. Vol.27, Issue \$, pp 521 -539.

Sadasivam S. and Manickam A. (2008). Biochemical Method, 3 ${ }^{\text {rd }}$ ed. Publi. New age international (P) Ltd. New Delhi (pp8, 22, 58) Thajuddin N and Subramaian G. (2005). Cyanobacterial biodiversity and potential application in biotechnology. Current Science Vol 89: 47-57

Y.K.Chau. (1967). The component Combined amino acids of some marine phytoplankton species. J.Mar.Biol.Ass.U.K.47,pp 543-554

Table I: Shows Chlorophyll a, Chlorophyll b and Total carotenoid content of Spirulina platensis, Nostoc elipsosporum and Oscillatoria $s p$.

\begin{tabular}{|c|c|c|c|}
\hline $\begin{array}{c}\text { Name of algal } \\
\text { material }\end{array}$ & $\begin{array}{c}\text { Chlorophyll a content } \\
\text { (ug/gm fw) }\end{array}$ & $\begin{array}{c}\text { Chlorophyll b content } \\
\text { (ug/gm fw) }\end{array}$ & $\begin{array}{c}\text { Total Carotenoids } \\
\text { content } \\
\text { (ug/gm fw) }\end{array}$ \\
\hline Spirulina platensis & 9.498 & 5.4223 & 0.233 \\
\hline Nostoc elipsosporum & 13.42 & 2.2814 & 2.0484 \\
\hline Oscillatoria $s p$ & 2.5701 & 1.38 & 0.425 \\
\hline
\end{tabular}


Table II: Shows Carbohydrate, protein and Lipid content of Spirulina platensis, Nostoc elipsosporum and Oscillatoria $s p$.

\begin{tabular}{|c|c|c|c|}
\hline $\begin{array}{c}\text { Name of algal } \\
\text { material }\end{array}$ & $\begin{array}{c}\text { Total Carbohydrate } \\
\text { contain (\%/gm ) }\end{array}$ & $\begin{array}{c}\text { Protien(\%/gm of dry } \\
\text { mass) }\end{array}$ & $\begin{array}{c}\text { Lipid (\% / gm of dry } \\
\text { mass) }\end{array}$ \\
\hline Spirulina platensis & 6.0 & 60.0 & 4.0 \\
\hline Nostoc elipsosporum & 12.00 & 33.0 & 10.11 \\
\hline Oscillatoria $s p$ & 21.00 & 22.5 & 3.0 \\
\hline
\end{tabular}

Table III: Shows different type of amino acids present in Spirulina platensis, Nostoc elipsosporum and Oscillatoria sp.

\begin{tabular}{|c|c|c|c|}
\hline Name of amino acid & Spirulina platensis & Nostoc elipsosporum & Oscillatoria sp. \\
\hline Aspartic acid & + & + & + \\
\hline Glutamic Acid & + & + & + \\
\hline Serine & + & + & + \\
\hline Histidine & + & + & + \\
\hline Glycine & + & + & + \\
\hline Arginine & + & + & + \\
\hline Tyrosine & + & + & - \\
\hline Valnine & + & + & + \\
\hline Methionine & + & + & + \\
\hline Phenylalanine & + & + & + \\
\hline Leucine & + & + & + \\
\hline Lysine & + & + & + \\
\hline proline & + & + & + \\
\hline
\end{tabular}

